\title{
高速炉自然循環崩壊熱除去時炉心内熱流動現象に対する プラント動特性解析コードの適用性に関する研究
}

\section{浜瀬 枝里菜*1，堂田 哲広*2，鍋島 邦彦*1，小野 綾子*2，大島 宏之*2 \\ Study on applicability of fast reactor plant dynamics analysis code to core thermal hydraulics under natural circulation decay heat removal conditions}

\author{
Erina HAMASE ${ }^{* 1}$, Norihiro DODA ${ }^{* 2}$, Kunihiko NABESHIMA ${ }^{* 1}$, \\ Ayako ONO $^{* 2}$ and Hiroyuki OHSHIMA*2 \\ ${ }^{* 1,{ }^{2}}$ Japan Atomic Energy Agency \\ 4002 Narita-cho, O-arai-machi, Higashiibaraki-gun, Ibaraki 311-1393, Japan
}

Received: 10 February 2017; Accepted: 30 March 2017

\begin{abstract}
A plant dynamics analysis code named Super-COPD is being developed in Japan Atomic Energy Agency (JAEA) to offer a methodology for the design and safety assessments of future commercialized sodium-cooled fast reactors (SFRs). In this study, the friction loss coefficients in the whole core thermal-hydraulic model, which is based on flow network modeling, was modified to improve the prediction accuracy of the sodium temperature distribution in a fuel subassembly under the natural circulation conditions. Super-COPD with the modified whole core model was applied to analyses of experiments, that were performed by using JAEA's test facility PLANDTL and were simulated natural circulation decay heat removal operations in SFRs, as a part of the code validation study. The obtained numerical results of sodium temperature distributions in the core showed good agreement with the measured data. It implies that the modified whole core model can properly reproduce dominant thermal-hydraulic phenomena in the core region under natural circulation conditions, i.e., flow redistribution among fuel subassemblies as well as in a fuel subassembly and inter-subassembly heat transfer.
\end{abstract}

Key words : Sodium-cooled fast reactor, Natural circulation decay heat removal, Plant dynamics analysis code, Whole core model

\section{1. 緒 言}

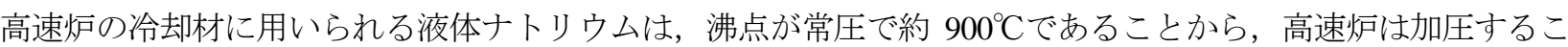
となく熱効率上有利となる高い運転温度を設定することが可能であり，また原子炬出入口温度差も大きくなる. このため系統機器（炉心，中間熱交換器，空気冷却器など）の高低差や圧力損失を適切に設計することで，冷却 材の密度差によって生じる浮力により系統内の冷却材を循環させ，ポンプ等の動的機器に依存せずに空気を除熱 源として炉心の崩壊熱を除去することが可能となる．日本原子力研究開発機構（JAEA）では，ナトリウム冷却高 速炉の実用化に向けて，この自然循環を活用した崩壊熱除去系の成立性・信頼性を評価するために，解析手法の 整備を実施している（Watanabe et al., 2015）.

自然循環崩壊熱除去時の炉心内熱流動を解析するにあたっては，次の現象を考慮する必要がある．第一は然料 集合体内／間流量再配分現象であり，浮力の効果により燃料集合体内の高温領域および炉心内高温集合体により

No.16-00431 [DOI:10.1299/transjsme.16-00431], J-STAGE Advance Publication date: 12 April, 2017

*1 日本原子力研究開発機構（广311-1393 茨城県東茨城郡大洗町成田町 4002）

*2 正員，日本原子力研究開発機構

E-mail of corresponding author: hamase.erina@jaea.go.jp 
多くのナトリウムが配分される現象である．第二は隣接する燃料集合体間の熱移行（集合体間熱移行現象）であ り，低流量時は対流熱輸送による燃料除熱が減少するため，相対的にその効果が大きくなる．第三は燃料集合体 間ギャップ部流れ (インターラッパフロー) であり, 集合体間の熱移行の促進，さらには炕心部の熱除去に寄与 する効果がある．これらの熱流動現象により，自然循環崩壊熱除去時の炉心内温度分布は強制循環時に比べて平 坦化される（Kamide et al., 1998; Nishimura et al., 2000; Kamide et al., 2001）.

JAEA では，これらの熱流動現象をすべて考慮した全炉心熱流動モデル（Watanabe et al., 1997）をプラント動特 性解析コードSuper-COPD に組み込み, 自然循環崩壊熱除去時の炉心内熱流動挙動を評価できる手法を整備して きた（Oyama et al., 2016; Doda et al., 2016）．本研究では，予測精度向上のために本モデルの一部を改良するととも に，モデルの妥当性確認の一環として，集合体間に有意な温度差のある条件で実施したナトリウム試験を対象に 解析を実施し，その適用性を検討する.

\section{2.ナトリウム試験装置概要}

本研究で解析対象とする試験は, JAEA のナトリウム伝熱流動試験装置 PLAnt Dynamic Test Loop (PLANDTL) を用いて実施されたものである (Ono et al., 2016). PLANDTL は 1 次系, 2 次系, 崩壊熱除去系から成る（図 1)

(Kamide et al., 2001). 1 次系は 7 体の模擬燃料集合体で構成された模擬炉心部，上部プレナム，中間熱交換器， 主循環ポンプ, 下部プレナムから構成されている. 2 次系には空気冷却器を備え, 中間熱交換器を介して輸送さ れた模擬炉心の熱は大気中に放出される，崩壊熱除去系としては，上部プレナム内に直接炉心冷却系（DRACS） 熱交換器, 中間熱交換器内には 1 次系炉心冷却系（PRACS）に対応した熱交換器が設置されており，いずれも空 気冷却器に接続されている.

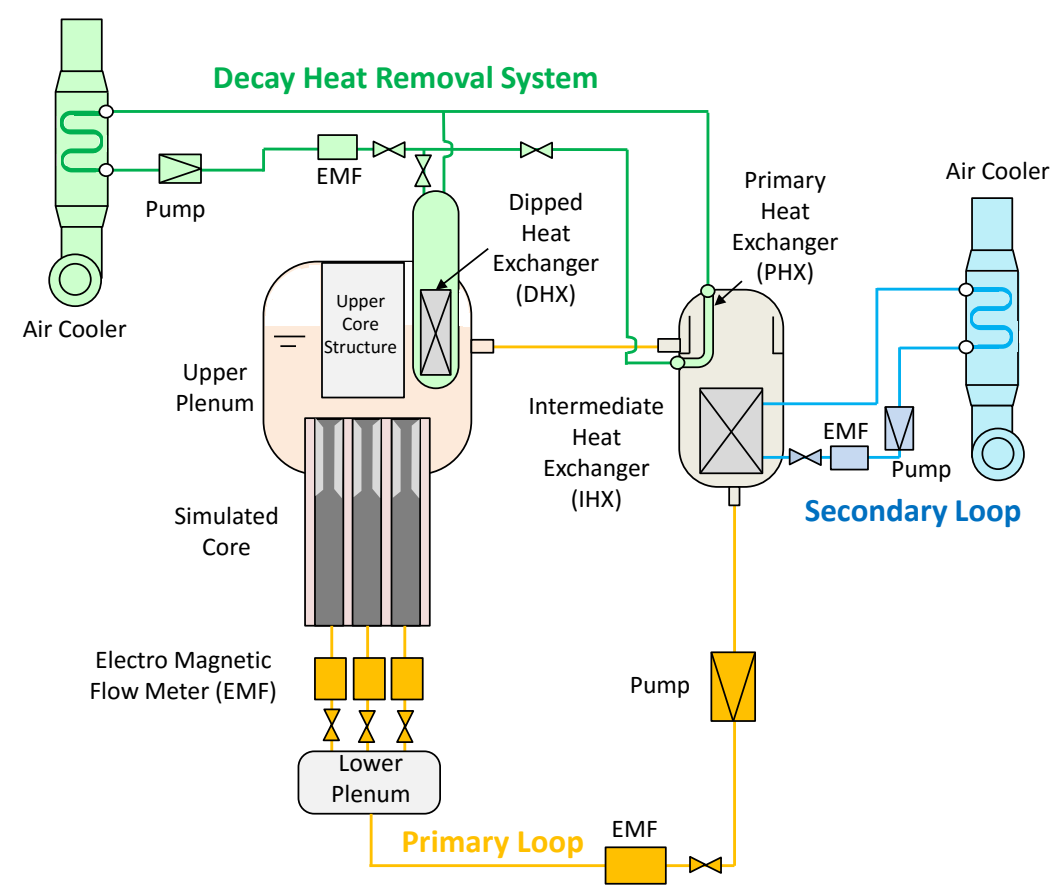

Fig. 1 Layout of components in PLANDTL facility.

PLANDTL の模擬炉心部を図 2 に示す．模擬炉心部は，中心集合体 1 体と周辺集合体 6 体 $(\mathrm{A} \sim \mathrm{F})$ の計 7 体の 模擬燃料集合体から成る. 模擬炉心部への入口流路は 3 本あり, 1 本は中心集合体に, 2 本は周辺集合体 $\mathrm{A} \sim \mathrm{C}$, $\mathrm{D} \sim \mathrm{F}$ の 3 体ずつに接続されている. 中心集合体は螺旋状に巻かれたワイヤースペーサを有する模擬燃料ピン（ヒ ータピン） 37 本およびそれを収納する六角柱状のラッパ管から構成されている. 中心集合体のヒータピン径, 配 列ピッチ, ワイヤースペーサ径, 巻きピッチ, 発熱部長さは実機相当であり, その軸方向出力分布はチョップド コサインである。一方，周辺集合体は 7 本の模擬然料ピンから構成され，中心集合体および集合体間ギャップ部 
に対して熱的な境界条件を与える目的で設置されている. 各集合体の径方向のサイズは実機の半分程度となるも のの，集合体間ギャップ幅は実機相当であり，集合体内の流量再配分を伴う集合体間熱移行やインターラッパフ ロー等の現象に着目した試験が可能である. 表 1 に模擬燃料集合体の仕様を示す．図 2 に示すように，熱電対を 用いてヒータピン発熱部上端・中間・下端高さの集合体内および集合体間ギャップ部の水平断面内冷却材温度分 布が計測されている.
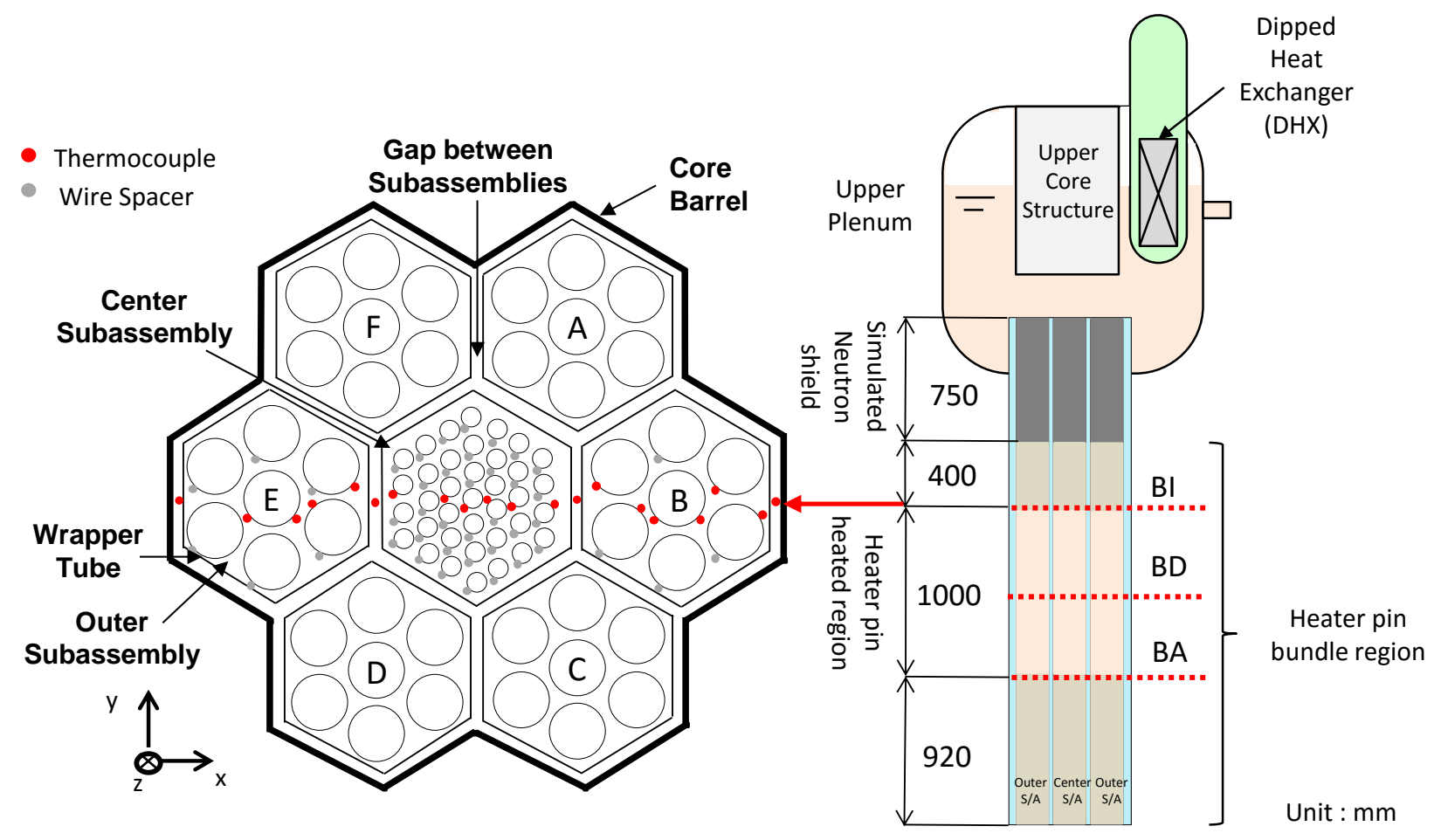

Fig. 2 Schematic of simulated core region.

Table 1 Specifications of simulated core region.

\begin{tabular}{|l|l|c|c|c|}
\hline & \multicolumn{1}{|c|}{ Item } & unit & $\begin{array}{c}\text { Center } \\
\text { Subassembly }\end{array}$ & $\begin{array}{c}\text { Outer } \\
\text { Subassembly }\end{array}$ \\
\hline Subassembly & Number & - & 1 & 6 \\
\hline & Flat to flat distance of subassembly & $\mathrm{m}$ & 0.071 & 0.071 \\
\hline & Flat to flat distance of hexagonal flow area & $\mathrm{m}$ & 0.063 & 0.063 \\
\hline & Wrapper tube thickness & $\mathrm{m}$ & 0.004 & 0.004 \\
\hline & Subassembly pitch & $\mathrm{m}$ & 0.078 & 0.078 \\
\hline & Inter-wrapper gap width & $\mathrm{m}$ & 0.007 & 0.007 \\
\hline & Number & - & 37 & 7 \\
\hline & Pin pitch & $\mathrm{m}$ & 0.0099 & 0.0224 \\
\hline & Pellet diameter & $\mathrm{m}$ & 0.0067 & 0.0178 \\
\hline & Pin diameter & $\mathrm{m}$ & 0.0083 & 0.0208 \\
\hline & Cladding thickness & $\mathrm{m}$ & 0.0008 & 0.0015 \\
\hline & Diameter & $\mathrm{m}$ & 0.0015 & 0.0015 \\
\hline & Wire lead & $\mathrm{m}$ & 0.165 & 0.165 \\
\hline
\end{tabular}




\section{$3 \cdot 1$ 全炉心熱流動モデル}

\section{3. 解析モデル}

全炉心熱流動モデルでは，自然循環崩壊熱除去時の各集合体内の浮力および圧損特性による集合体間の流量再 配分を考慮するため, 図 3 （a）に示すように然料集合体，ブランケット燃料集合体，中性子遮へい体および制御 棒チャンネルなどの炬心槽内全ての構成要素を 1 体ずつチャンネルで模擬するマルチチャンネルモデルを採用し ている. 各然料/ブランケット燃料集合体チャンネルの流動は, チャンネル出入口差圧等価条件および浮力やワ イヤースペーサ型然料ピンバンドルの流動抵抗（Cheng and Todreas, 1986）を考慮した運動量保存式から算出され る.また炉心槽内のインターラッパフローについては，図 3 （b）に示すように流路を 1 次元の枝要素を組み合わ せたフローネットワークモデルで模擬している，さらに，集合体間流量再配分に影響する集合体間熱移行を考慮 するため，集合体内ナトリウムのラッパ管近傍の温度を見積もる必要がある，そこで，集合体内については，図 3 （c）に示すように集合体内ナトリウムを水平断面で中心 1 領域（図 3 (c) のピンク色領域）とその外側のラッ パ管頂点に沿った周辺 6 領域（pi=1〜6）に分割し, 中心一周辺領域間の流量配分やエネルギ混合を考慮する. 得 られた集合体内ナトリウムのラッパ管近傍温度と，ラッパ管温度及び集合体間ギャップ部ナトリウム温度を用い て集合体間の熱移行量を得る.

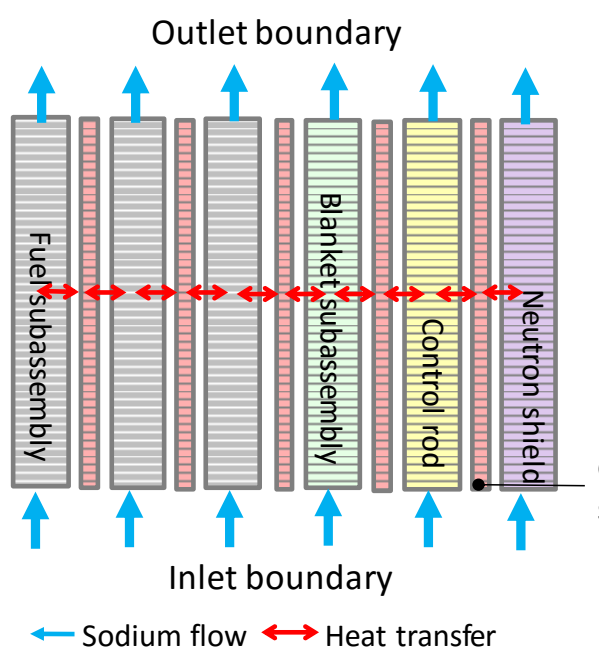

(a) Whole core multi-channel model

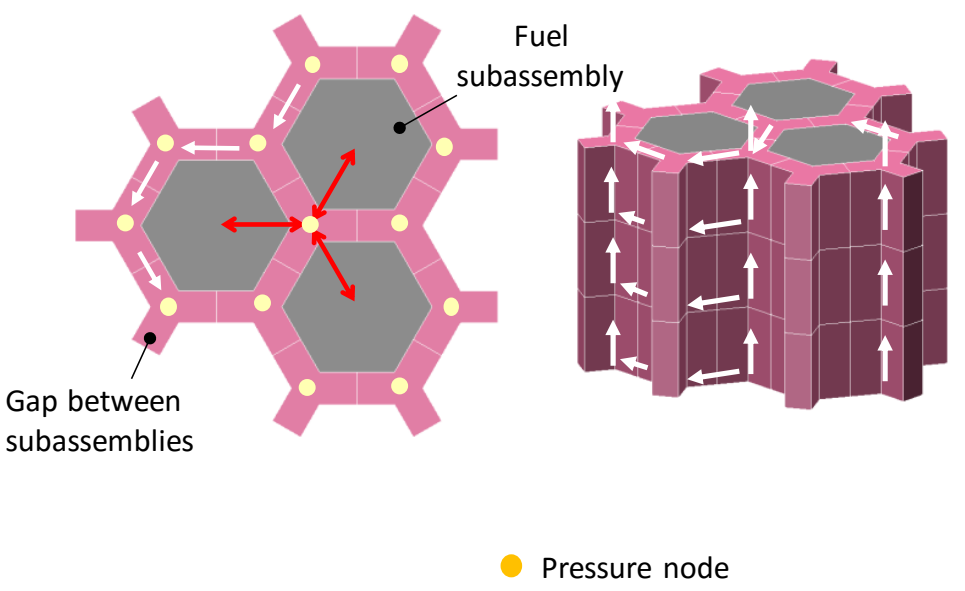

(b) Flow network model in gaps between subassemblies

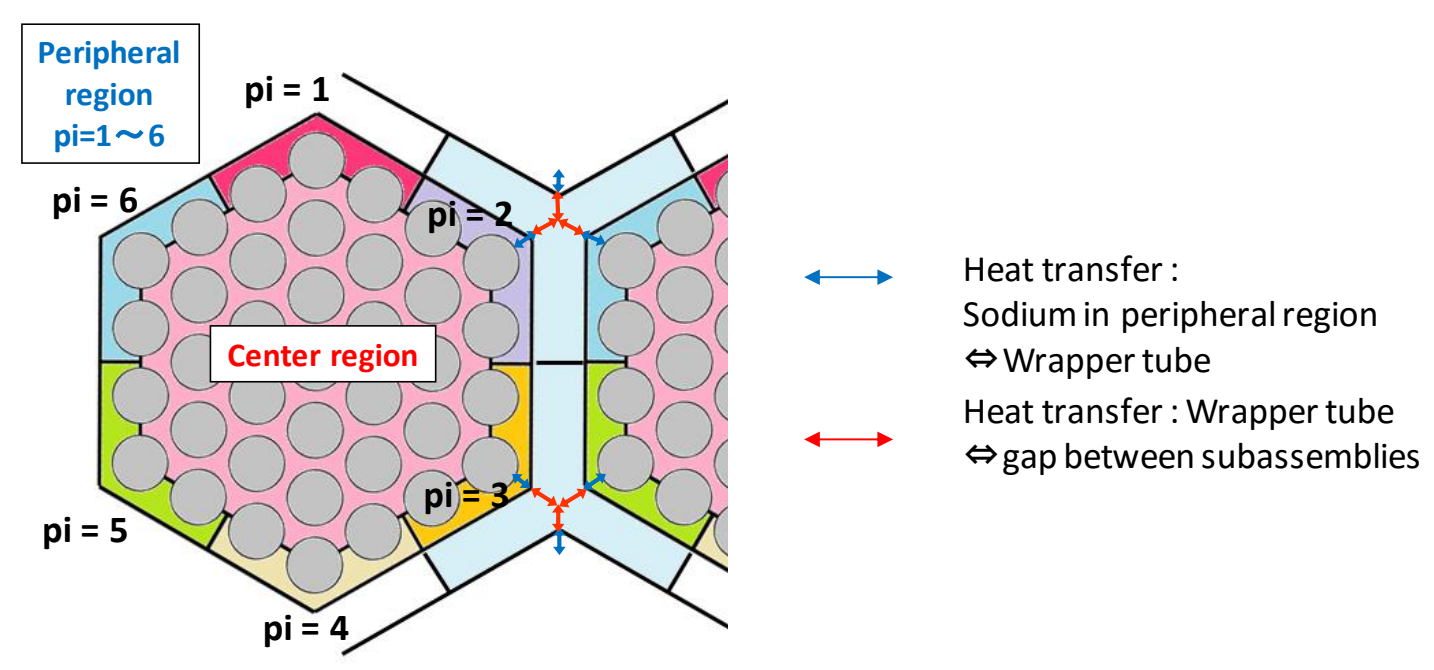

(c) Inter-subassembly heat transfer model

Fig. 3 Whole core thermal hydraulics model. 
ラッパ管内壁面の熱伝達評価には式（1）（Subbotin et al., 1962）を用い，ラッパ管外壁面については Pe 数のオー ダーが 1 程度（集合体間ギャップ部ナトリウム流速が数 $\mathrm{cm} / \mathrm{s}$ 程度）となることから熱伝導相当とする.

$$
N u=5+0.025 P e^{0.8}
$$

\section{$3 \cdot 2$ 集合体内周辺領域平均摩擦損失係数導出方法の見直し}

図 4 に本研究の解析対象である PLANDTL の 37 本ヒータピンから成る中心集合体および 7 本ヒータピンから 成る周辺集合体における周辺領域の 1 領域（図 $3(\mathrm{c})$ における $\mathrm{pi}=2$ ) を拡大したものを示す. 本モデルの周辺 1 領域はサブチャンネル解析手法におけるエッジサブチャンネルとコーナーサブチャンネルで構成されることに なる。

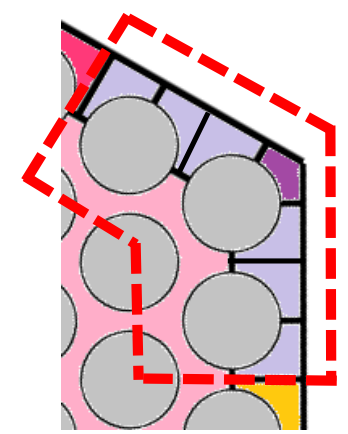

37 pins

Edge: Corner $=6: 1$

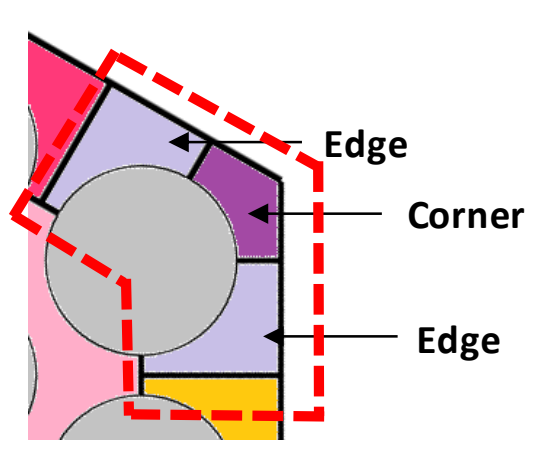

7 pins

Edge: Corner = $2: 1$

Fig. 4 Enlarged view of one peripheral region in 7 and 37 pin bundle.

この周辺領域の温度を精度良く評価するためには, 集合体内中心領域と各周辺領域間の流量配分が適切に行わ れる必要がある. Super-COPD の従来モデルでは, エッジ, コーナーサブチャンネルにおける摩擦損失係数に各サ ブチャンネル領域の流路断面積で重み付けを行い, 集合体周辺領域平均の摩擦損失係数 $f_{\text {peri }}$ を導出していた.

$$
f_{\text {peri }}=\frac{A_{e}}{A_{c}+A_{e}} f_{e}+\frac{A_{c}}{A_{c}+A_{e}} f_{c}
$$

ここで, $\mathrm{A}$ は冷却材流路断面積, $f$ は摩擦損失係数, 添え字 $\mathrm{e}$ はエッジ, $\mathrm{c}$ はコーナーを表す. また, サブチャン ネルの摩擦損失係数にはワイヤースペーサ型燃料集合体ピンバンドルの実験相関式（Cheng and Todreas, 1986）が 用いられる。

$$
f_{i}=\frac{C_{f i}}{R e_{i}^{m}}
$$

ここで, $\mathrm{Re}_{i}$ はレイノルズ数を表し, 摩擦損失定数 $C_{f i}$ と累乗指数 $\mathrm{m}$ (層流領域 : 1.0 , 乱流領域 : 0.18 ) は測定デー タに基づいた定数パラメータである.

しかしながら，式 (2) は両サブチャンネルの流速が等しい場合を仮定した計算式であるため，エッジサブチャ ンネルよりも大きい摩擦損失係数を持つコーナーサブチャンネルへの流量配分が多くなり, 結果として, 算出さ れた集合体周辺領域平均の摩擦損失係数は過大に評価される. 特に, 図 4 の 7 本ヒータピンから成る周辺集合体 のようにエッジとコーナーサブチャンネルの個数比が拮抗する体系ではこの違いが無視できないと考えられる. そこで本研究では, Cheng らの燃料ピンバンドル平均の摩擦損失係数の導出方法（Cheng and Todreas, 1986）にな 
らい, 集合体内周辺領域平均の摩擦損失係数を導出した. まず，運動量について，エッジとコーナーサブチャン ネルの集合体内周辺領域出入口差圧の等価条件から式（4）が成り立つ.

$$
\Delta P_{\text {peri }}=\Delta P_{e}=\Delta P_{c}=f_{i} \frac{L}{D e_{i}} \frac{\rho V_{i}^{2}}{2}
$$

ここで， $\Delta \mathrm{P}$ は集合体出入口差圧，Lは燃料ピンバンドル長さ，Deは水力等価直径， $\rho$ は冷却材密度，Vは軸方向流 速であり，添え字iはエッジ (e)，コーナー（c）または集合体内周辺領域（peri）である.サブチャンネル間で冷 却材密度と燃料ピンバンドル長さは等しいと仮定すると, 式 (4) は以下のように変形される.

$$
\frac{f_{\text {peri }}}{D e_{\text {peri }}}=\frac{f_{e}}{D e_{e}}\left(\frac{V_{e}}{V_{\text {peri }}}\right)^{2}=\frac{f_{c}}{D e_{c}}\left(\frac{V_{c}}{V_{\text {peri }}}\right)^{2}
$$

以下の関係式,

$$
R e_{i}=R e_{\text {peri }}\left(\frac{D e_{i}}{D e_{\text {peri }}}\right)\left(\frac{V_{i}}{V_{\text {peri }}}\right)
$$

を代入した式（3）を式（5）に代入することにより，エッジおよびコーナーサブチャンネルの流速比および集合 体内周辺領域平均摩擦損失定数を求める次の関係式が導かれる.

$$
\begin{aligned}
& \frac{V_{c}}{V_{e}}=\left(\frac{D e_{c}}{D e_{e}}\right)^{\frac{1+m}{2-m}}\left(\frac{C_{f e}}{C_{f c}}\right)^{\frac{1}{2-m}} \\
& C_{\text {fperi }}=C_{f e}\left(\frac{D e_{\text {peri }}}{D e_{e}}\right)^{1+m}\left(\frac{V_{e}}{V_{\text {peri }}}\right)^{2-m}
\end{aligned}
$$

一方，式（9）に示寸質量流量の保存則から,

$$
\rho A_{e} V_{e}+\rho A_{c} V_{c}=\rho A_{\text {peri }} V_{\text {peri }}
$$

以下の関係が成り立つ.

$$
\frac{V_{e}}{V_{\text {peri }}}=\frac{1}{\frac{A_{e}}{A_{\text {peri }}}+\frac{V_{c}}{V_{e}} \frac{A_{c}}{A_{\text {peri }}}}
$$

式（7）を式（10）に代入したものをさらに式（8）に代入すると, 集合体内周辺領域平均摩擦損失定数 $C_{f p e r i}$ は以 下のように導出され，

$$
C_{f p e r i}=D e_{\text {peri }}\left[\frac{A_{e}}{A_{\text {peri }}}\left(\frac{D e_{e}}{D e_{\text {peri }}}\right)^{\frac{m}{(2-m)}}\left(\frac{C_{f e}}{D e_{e}}\right)^{\frac{1}{(m-2)}}+\frac{A_{c}}{A_{\text {peri }}}\left(\frac{D e_{c}}{D e_{\text {peri }}}\right)^{\frac{m}{(2-m)}}\left(\frac{C_{f c}}{D e_{c}}\right)^{\frac{1}{(m-2)}}\right]^{m-2}
$$

式 (3) に代入すると, 集合体内周辺領域平均摩擦損失係数 $f_{p e r i}$ が得られる. 


$$
f_{\text {peri }}=\frac{D e_{\text {peri }}}{R e_{\text {peri }}{ }^{m}}\left[\frac{A_{e}}{A_{\text {peri }}}\left(\frac{D e_{e}}{D e_{\text {peri }}}\right)^{\frac{m}{(2-m)}}\left(\frac{C_{f e}}{D e_{e}}\right)^{\frac{1}{(m-2)}}+\frac{A_{c}}{A_{\text {peri }}}\left(\frac{D e_{c}}{D e_{\text {peri }}}\right)^{\frac{m}{(2-m)}}\left(\frac{C_{f c}}{D e_{c}}\right)^{\frac{1}{(m-2)}}\right]^{m-2}
$$

以上のように導出した式（12）を用いて，PLANDTL の中心集合体および周辺集合体の集合体内周辺領域平均摩 擦損失係数 $f_{p e r i}$ を計算した結果を図 5 に示寸. 表 2 にここで用いたパラメータ值を示す. 37 本ヒータピンから成 る中心集合体では，式（12）の結果は式（2）を用いて計算した結果とほぼ一致するのに対し，7本ヒータピンか ら成る周辺集合体では, 式 (12) の結果は式 (2) の結果よりも摩擦損失係数 $f_{\text {peri }}$ を小さく見積もることが分かる.

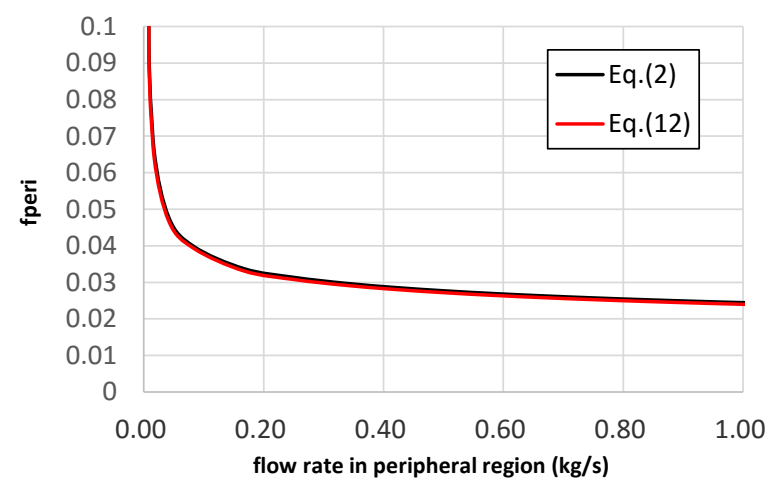

(a) Center subassembly (37 pins)

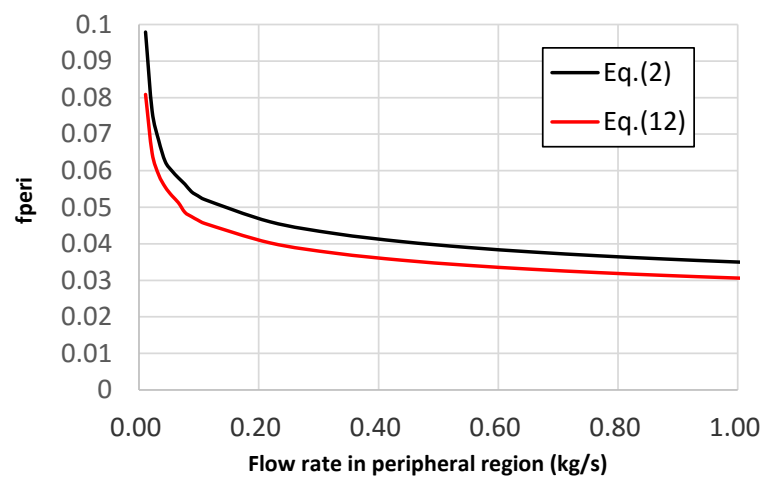

(b) Outer subassembly (7 pins)

Fig. 5 Friction loss coefficient at the peripheral region with eq. (2) and eq. (12) in the center and outer subassembly of PLANDTL.

Table 2 Parameters for friction loss coefficient.

\begin{tabular}{|c|c|c|c|c|c|c|c|}
\hline \multirow{2}{*}{ Item } & \multirow{2}{*}{ unit } & \multicolumn{2}{|c|}{ Center subassembly } & \multicolumn{3}{|c|}{ Outer subassembly } \\
\cline { 4 - 7 } & & Edge & Corner & Peripheral & Edge & Corner & Peripheral \\
\hline Axial flow area $(\mathrm{A})$ & $\mathrm{m}^{2}$ & $8.78 \times 10^{-5}$ & $9.97 \times 10^{-6}$ & $9.78 \times 10^{-5}$ & $1.00 \times 10^{-4}$ & $2.76 \times 10^{-5}$ & $1.28 \times 10^{-4}$ \\
\hline Axial length $(\mathrm{L})$ & $\mathrm{m}$ & \multicolumn{5}{|c|}{2.32} \\
\hline Equivalent hydraulic diameter $(\mathrm{De})$ & $\mathrm{m}$ & $4.62 \times 10^{-3}$ & $3.37 \times 10^{-3}$ & $4.45 \times 10^{-3}$ & $6.96 \times 10^{-3}$ & $4.29 \times 10^{-3}$ & $6.13 \times 10^{-3}$ \\
\hline
\end{tabular}

\section{4. 試験解析}

\section{$4 \cdot 1$ 解析条件}

解析領域は図 2 に示す模擬炉心部とした，境界条件としては，各集合体のナトリウム入口温度，流量およびヒ ータピン出力を与え, 炉心槽壁面は断熱条件とした. 軸方向メッシュ分割は集合体下端から上端まで 80 メッシュ としている．解析対象試験は，中心集合体および周辺集合体間に熱移行が生じるように集合体間に有意な温度差 を設定した定常試験 2 ケースとした. 表 3 に両ケースの出力・流量条件および然料ピンバンドル入口平均 Re 数 を示す．ケース 1 は中心集合体が周辺集合体 6 体から加熱されるケース，ケース 2 は中心集合体が周辺集合体 6 体から冷却されるケースであり，両ケースとも中心および周辺集合体流量は自然循環崩壊熱除去時流量（実機定 格運転時の $2 \sim 4 \%$ ) に相当する. 本解析では, 前章の集合体内周辺領域平均摩擦損失係数の見直しにより導出 した $f_{\text {peri }}$ (式 (12)) を用いるとともに, 既往解析モデルにおける $f_{\text {peri }}$ (式 (2)) を用いた解析結果との比較を行 った. また自然循環崩壊熱除去時における集合体間熱移行の効果を調べるため，集合体間熱移行の効果を排除し たラッパ管外壁面に断熱条件を仮定した解析も実施した. 
Table 3 Experimental conditions.

\begin{tabular}{|c|c|c|c|c|}
\hline & \multicolumn{2}{|c|}{ Case 1 } & \multicolumn{2}{c|}{ Case 2 } \\
\cline { 2 - 5 } & $\begin{array}{c}\text { Center } \\
\text { Subassembly }\end{array}$ & $\begin{array}{c}\text { Outer } \\
\text { Subassembly }\end{array}$ & $\begin{array}{c}\text { Center } \\
\text { Subassembly }\end{array}$ & $\begin{array}{c}\text { Outer } \\
\text { Subassembly }\end{array}$ \\
\hline Power(P)* & $1.9 \%$ & $4.1 \%$ & $1.9 \%$ & $2.3 \%$ \\
\hline Flow rate (F)* & $2.4 \%$ & $3.6 \%$ & $2.5 \%$ & $3.6 \%$ \\
\hline P/F & 0.79 & 1.1 & 0.76 & 0.64 \\
\hline $\begin{array}{c}\text { Fuel pin bundle } \\
\text { inlet averaged } \\
\text { Re }\end{array}$ & $1.2 \times 10^{3}$ & $3.5 \times 10^{3}$ & $1.3 \times 10^{3}$ & $3.5 \times 10^{3}$ \\
\hline
\end{tabular}

* means ratio to full-power condition of fuel subassembly in a fast reactor.

\section{$4 \cdot 2$ 解析結果}

図 6 に式（12）の $f_{\text {peri }}$ を用いて実施した解析結果を示寸. 図 6 (a)，(b) はケース 1 およびケース 2 のヒータ ピン発熱部上端 (黒線) ・ 中間 (赤線) ・ 下端（青線）の $270^{\circ}-90^{\circ}$ 方向水平断面におけるナトリウム温度の解 析結果（実線）と試験結果（白抜き）である. 解析結果から算出した中心集合体と 6 体の周辺集合体間の熱移行 量は，ケース 1 が中心集合体出力の $18.9 \%$ ，ケース 2 が $6.3 \%$ に相当する. 3 つの集合体内（中心集合体および周 辺集合体 B，F）のヒータピン発熱部上端・中間における中心および周辺領域温度は，試験結果とおおむね一致し ている様子が確認できる，集合体内中心および周辺領域温度のヒータピン発熱部下端から上端または中間までの

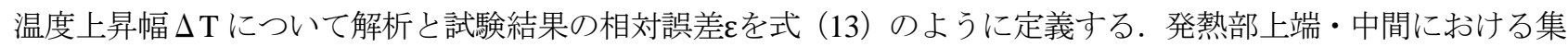
合体内中心領域には熱電対が $3 \sim 6$ 本設置されているが，全炉心熱流動モデルでは中心領域温度が 1 点で評価さ れることから，比較のため試験結果における中心領域温度については加算平均とした．相対誤差をを求めたとこ 万，発熱部上端ではケース 1 で最大 $2.5 \%$ ，ケース 2 で $4.3 \%$ ，発熱部中間ではケース 1 で最大 $5.2 \%$ ，ケース 2 で $6.2 \%$ となり，集合体内流量再配分や集合体間熱移行により形成される集合体水平断面内温度分布をよく再現でき ることを確認した.

$$
\varepsilon=\frac{\Delta T_{c a l}-\Delta T_{\text {exp }}}{\Delta T_{\text {exp }}}
$$

図 6 と同様に, 図 7 に既往解析モデルにおける $f_{p e r i}$ を用いた解析結果を示寸. 7 本ヒータピンから成る周辺集 合体 $\mathrm{B}$ および $\mathrm{E}$ に着目すると，発熱部上端における集合体内中心領域温度は，試験結果に比べてケース 1 で平均 $8.5{ }^{\circ} \mathrm{C}$, ケース 2 で平均 $7.3{ }^{\circ} \mathrm{C}$ 低く評価されており, 導出方法を見直した $f_{\text {peri }}$ を用いて実施した解析結果と比べ て集合体内温度分布の模擬性が低いことが分かる．これにより $f_{\text {peri }}$ 導出方法の見直しが，集合体内中心領域と周 辺領域一の流量配分模擬性を改善し，集合体水平断面内温度分布の予測精度向上に有効であることを確認した.

集合体間熱移行の効果を確認するために，ケース 1 および 2 に対してラッパ管外壁面に断熱条件を仮定し熱移 行の効果を排除した解析結果を図 8 に示す，高温集合体から低温集合体への熱移行が無いため，集合体内平均温 度は集合体出力と流量から決定されることになる，中心集合体に着目寸ると，ケース１では集合体間熱移行が考 慮された解析結果である図 6 (a) よりも平均温度が $29.9{ }^{\circ} \mathrm{C}$ 低く, ケース 2 では図 6 (b) よりも平均温度が $5.8{ }^{\circ} \mathrm{C}$ 高くなり，集合体間熱移行を考慮した場合よりも炉心内温度分布が急峻となることが分かる．図 8 (a)，(b) では 周辺集合体に比べて中心集合体において試験結果との温度差が大きいが，これは中心集合体 1 体に対して 6 体の 周辺集合体から授受する熱移行が考慮されなかったためである. 以上より，自然循環時には集合体間熱移行が炉 心内温度平坦化に影響を与えることを確認した。 


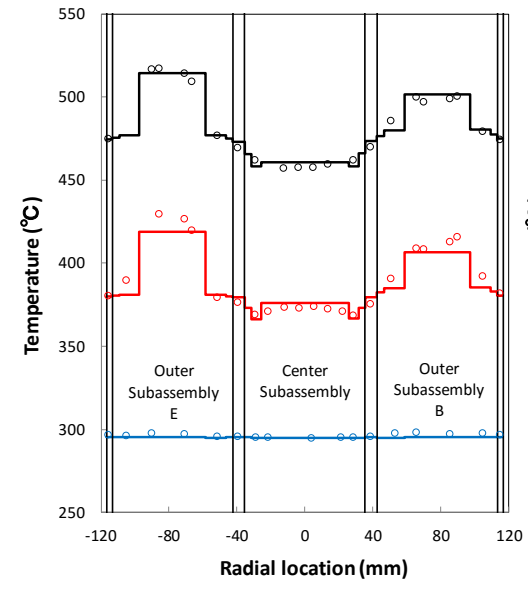

(a) Case 1

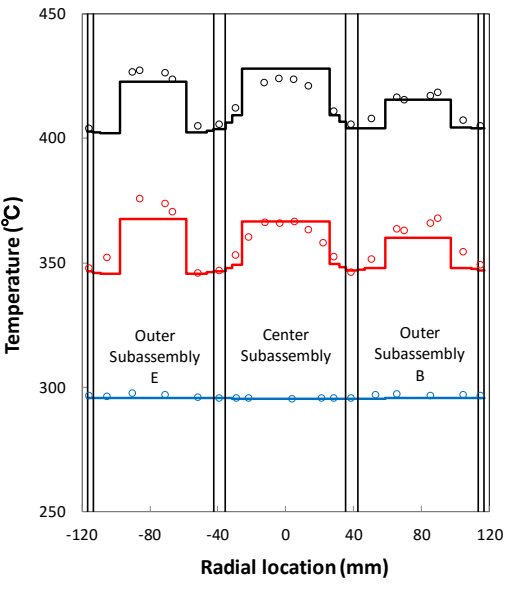

(b) Case 2

Fig. 6 Transverse sodium temperature distributions at top (black), middle (red) and bottom (blue) of heated length simulated with modified whole core model. Temperatures at the center and peripheral region in 3 subassemblies; center, and outer subassemblies B and F, were almost the same as the sodium temperatures obtained in experiments. In both cases, the coolant temperature difference between the bottom and upper heated section in center and peripheral region of subassembly as a principal evaluation parameter were consistent with the experimental data within relative error $2.5 \%$ and $4.3 \%$ respectively.

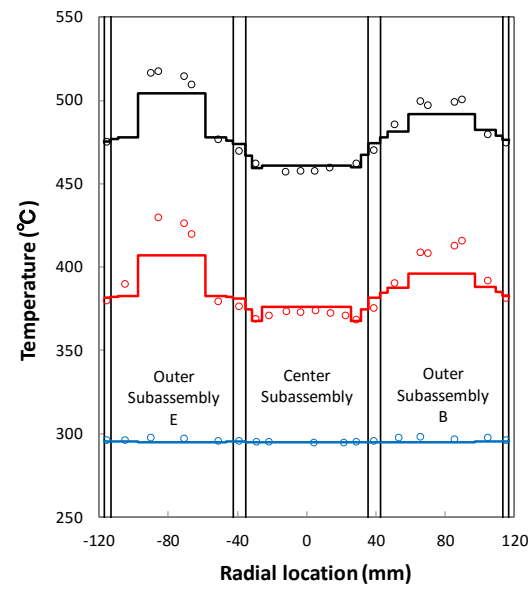

(a) Case 1

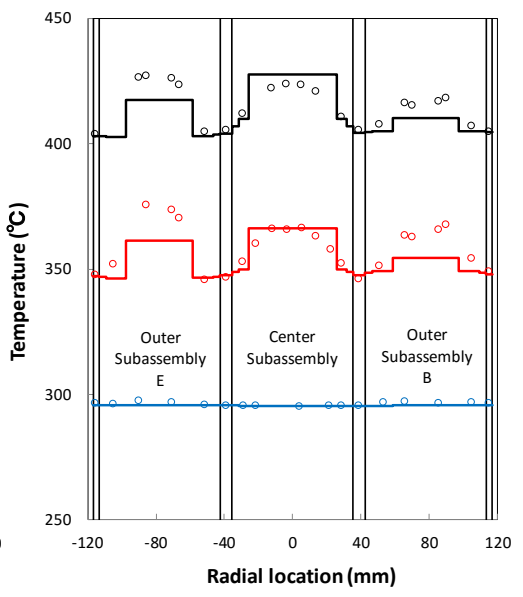

(b) Case 2

Fig. 7 Transverse sodium temperature distributions at top (black), middle (red) and bottom (blue) of heated length simulated with previous whole core model. Temperatures in the center region of outer subassembly were estimated lower than that of experimental data. 


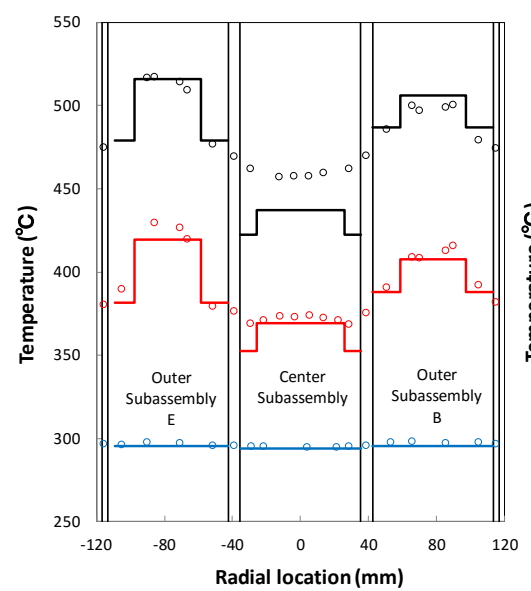

(a) Case 1

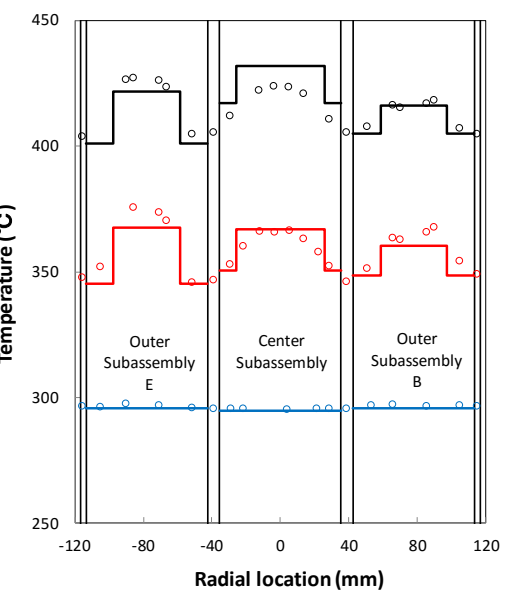

(b) Case 2

Fig. 8 Transverse sodium temperature distributions at top (black), middle (red) and bottom (blue) of heated length in condition of heat insulation around wrapper tube walls. Under natural circulation decay heat removal conditions, inter subassembly heat transfer plays an effective role in temperature flatting within the core.

\section{5. 結 言}

ナトリウム泠却高速炉プラント動特性解析コードについて, 自然循環崩壊熱除去時の炉心熱流動挙動の予測精 度向上のために全师心熱流動モデルの一部を改良するとともに，モデルの妥当性確認の一環として，自然循環崩 壊熱除去時の师心を模擬した定常ナトリウム試験を対象として解析を実施した．主な成果を以下にまとめる.

(1) 全炉心熱流動モデルについて, 燃料集合体内周辺領域の平均摩擦損失係数の導出方法を見直すことで, 燃料 集合体内中心領域と周辺領域一の流量配分模擬性の改善を図った.

（2）改良した全炉心熱流動モデルを定常ナトリウム試験解析に適用した結果，改良前に比して模擬炉心内ナトリ ウム温度分布の再現性が向上寸ることを確認した。これは圧力損失予測の改善によって，自然循環崩壊熱除 去時に強い相関を持つ燃料集合体内温度分布，流量配分，燃料集合体間熱移行量がより精度良く評価された 結果と考えられる.

（3）感度解析により，燃料集合体間熱移行現象が冷却材温度分布平坦化に与える影響を定量的に確認した.

\section{References}

Cheng, S. K. and Todreas, N. E., Hydrodynamic models and correlations for bare and wire-wrapped hexagonal rod bundles bundle friction factors, subchannel friction factors and mixing parameters, Nuclear Engineering and Design, Vol.92 (1986), pp.227-251.

Doda, N., Ohira, H. and Kamide, H., Benchmark analysis of EBR-II shutdown heat removal test-17 using of plant dynamics analysis code and subchannel analysis code, Proceedings of the 2016 International Congress on Advances in Nuclear Power Plants (ICAPP) (2016), pp. 1618-1625.

Kamide, H., Hayashi, K. and Toda, S., An experimental study of inter-subassembly heat transfer during natural circulation decay heat removal in fast breeder reactors, Nuclear Engineering and Design, Vol.183 (1998), pp.97-106.

Kamide, H., Hayashi, K., Isozaki, T. and Nishimura, M., Investigation of core thermohydraulics in fast reactors - interwrapper flow during natural circulation, Nuclear Technology, Vol.133 (2001), pp.77-91.

Nishimura, M., Kamide, H., Hayashi, K. and Momoi, K., Transient experiments on fast reactor core thermal-hydraulics and its numerical analysis inter-subassembly heat transfer and inter-wrapper flow under natural circulation conditions, Nuclear Engineering and Design, Vol.200 (2000), pp.157-175.

Oyama, K., Endo, J., Doda, N., Ono, A., Murakami, T. and Watanabe, O., Development of natural circulation analysis methods for a sodium cooled fast reactor, Journal of Nuclear Science and Technology, Vol. 53, No.3 (2016), pp. 353-370.

Ono, A., Kamide, H., Kobayashi, J., Doda, N. and Watanabe, O., An experimental study on natural circulation decay heat 
removal system for a loop type fast reactor, Journal of Nuclear Science and Technology, Vol.53, No.9 (2016), pp.13851396.

Subbotin, V. I., Papovyants, A. K., Kirillov, P. L. and Ivanovskii, N. N., A study of heat transfer to molten sodium in tubes, Translated from Atomnaya Energiya, Vol.13, No.4 (1962), pp.380-382.

Watanabe, O., Kotake, S., Kubo, S., Kajiwara, H. and Fujimata, K., Study on natural circulation evaluation method for a large FBR, Proceedings of $8^{\text {th }}$ international topical meeting on nuclear reactor thermal-hydraulics (NURETH-8) (1997), pp. 828-838.

Watanabe, O., Oyama, K., Endo, J., Doda, N., Ono, A., Kamide, H., Murakami, T. and Eguchi, Y., Development of an evaluation methodology for the natural circulation decay heat removal system in a sodium cooled fast reactor, Journal of Nuclear Science and Technology, Vol.52, No.9 (2015), pp.1102-1121. 